\title{
An overview of the academic level among EU countries. A cluster analysis approach
}

\author{
Mihail BUSU \\ Bucharest University of Economic Studies, Bucharest, Romania \\ mihail.busu@fabiz.ase.ro \\ Catalina NEDELCU \\ Bucharest University of Economic Studies, Bucharest, Romania \\ catalina.nedelcu@fabiz.ase.ro \\ Aura CADIS \\ Fundația Montessori Cluj, Cluj-Napoca, Romania \\ schule@montessori-cluj.ro
}

\begin{abstract}
The modernization of higher education is a complex process and occupies a priority place on the agenda of concerns both at European level and at the level of each member state of the European Union (EU). In this paper we present the results of the analysis of the main aspects of post-integration modernization of higher education in Romania, compared to the evolution in other Member States in the same period, from the perspective of five indicators: expenditure per student, percentage of GDP allocated to higher education, graduates per thousand inhabitants and professor per student's ratio. In order to achieve the proposed objective, we have carried out a research and a cluster analysis of data from secondary sources of available information, respectively reports of the European Commission and various statistical reports that will be mentioned throughout the article.
\end{abstract}

Keywords: higher education, academic level, EU countries, cluster analysis.

\section{Introduction}

The educational system is a vital area in the existence and evolution of any society. It not only generates knowledge and skills, but prepares new generations to take on specific responsibilities to contribute to the development of the society in which they operate.

Universities are important social partners with a major impact in teaching and learning, in developing the skills needed in the labor market, in generating and transferring knowledge, in supporting innovation and ensuring a substantial contribution to a modern and internationally integrated society.

At European Union (EU) level, education reform took place in Lisbon, with the adoption of the Bologna Declaration (July 19, 1999), signed by the ministers of education of 29 states, including Romania. The Bologna Declaration was signed by Romania in 1999, at the same time as other Eastern and Central European countries. Starting with 2005, the higher education programs are organized in three cycles: bachelor, master and doctorate, according to Law 288/2004. Also, the European Credit Transfer and Accumulation System (ECTS), as well as the diploma supplement were introduced as mandatory elements for each university in Romania.

This event of the implementation of the Bologna system, correlated with Romania's entry into the European Union in 2007, created the institutional framework for Romanian students to become eligible for European study programs.

DOI: $10.2478 /$ picbe-2021-0020

(C) 2021 M. Busu, C. Nedelcu, A. Cadis, published by Sciendo.

This work is licensed under the Creative Commons Attribution 4.0 License. 
In order to highlight the effects of the state of emergency at the level of the educational system and implicitly the proposed action plan, we developed an analysis of the educational sector, considering a set of relevant indicators, as follows: expenditure per student, \% GDP allocated to higher education, graduates per thousand inhabitants and professor per student's ratio at the 2019 level, but also compared to EU countries. The data used were extracted from databases: INS, Eurostat, Official Reports but also from other sources, frequently covered during this period.

\section{Literature review}

In Europe, the natural response to this trend towards the development of university education was the Lisbon Strategy, which grounded the focus of European higher education on innovation and technology transfer, with a focus on the knowledge-based society (Goia et al., 2017; Paunescu et al., 2017; Dubickis and Gaile-Sarkane, 2015).

The three defining aspects for the current objectives of the development strategies in the horizon 2020 - accessibility, retention / maintenance and employability - have enjoyed the attention of several specialists, not being the exclusive prerogative of studies conducted by European Commission institutions (Dima and Vasilache, 2016; Reinalda, 2008; Shattock, 2014; Curaj et al., 2015). At EU level, the participation rate of the population in higher education, calculated as a percentage ratio between the number of students and the total population, exceeded $10 \%$ only after the mid-50s and only in a few more developed countries (Koucky et al., 2010).

All students should have equal chances to get access to higher education. The use of their skills and talents would be of great benefit for the economy and society as a whole. Related to these factors, there are theories (Brennan et al., 2007) such as theories as cultural and social theory of socio-psychological model of the stratification process, which explains in what ways and to what extent educational systems in several countries have helped to remove the barriers in society or or tools to transmit the social status through generations.

Regarding the retention / retention of students in the curricula until completion, the specialists tried to elucidate which of the approaches is more explicit and correct: decreasing the degree of retention in curricula due to organizational culture and the quality of services of higher education institutions or determined by changes in lifestyle (Dima and Meghisan-Toma, 2018; Thomas, 2002), technological and economic factors, with all the implications on the level of productivity, diversification of specializations, family income, etc.

\section{Methodology}

For an in-depth analysis of Romania's position among EU member states, we performed a cluster analysis. Cluster analysis is an exploratory analysis that attempts to identify similar structures in data. Specifically, it tries to identify homogeneous groups of cases if the group to which it belongs is not previously known. The purpose of conducting a cluster analysis is to see in which group or category of countries Romania is, for each of the four calculated indicators. The cluster analysis was performed using SPSS 23 statistical software. The cluster analysis indicates Romania's position among EU member states, according to a series of main indicators on educational performance, namely: expenditures per student, percentage of GDP allocated to higher education, number of graduates per thousand inhabitants and ratio number of students per teacher.

We used the two-step cluster method to identify the groups, first performing pre-clustering and then executing hierarchical methods. Two-step clustering manages scale and ordinal data in the same model and automatically selects the number of clusters. For interval data, the most common is the squared Euclidean distance. It is based on the Euclidean distance between two 
observations which is the square root of the sum of the square distances. Because the Euclidean distance is square, it will increase the importance of long distances, while reducing the importance of short distances.

\section{Results and discussions}

A first result of the cluster analysis can be seen in the graph below.

Model Summary

\begin{tabular}{|l|l|}
\hline Algorithm & TwoStep \\
\hline Inputs & 4 \\
\hline Clusters & 5 \\
\hline
\end{tabular}

Cluster Quality

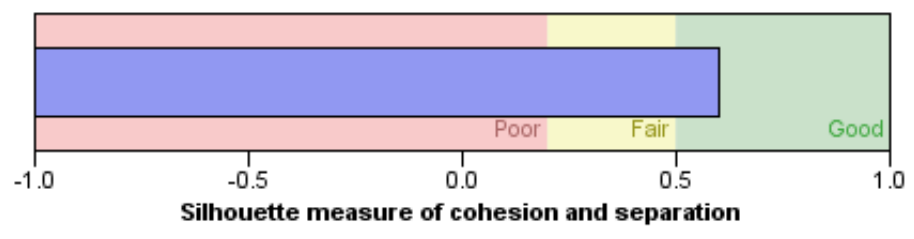

Figure 1. Cluster analysis of the data

Source: Eurostat and won computations, 2020.

As shown in this graph, the proposed clustering algorithm resulted in a number of 5 clusters (homogeneous data groups), in which EU Member States were divided based on the four selected indicators. Also, the "cluster quality" indicator in Figure 1 indicates that the cluster analysis performed in SPSS falls into the "good" category, which validates the result of the cluster analysis.

The following graph shows the number of countries in each cluster according to the four indicators analyzed.

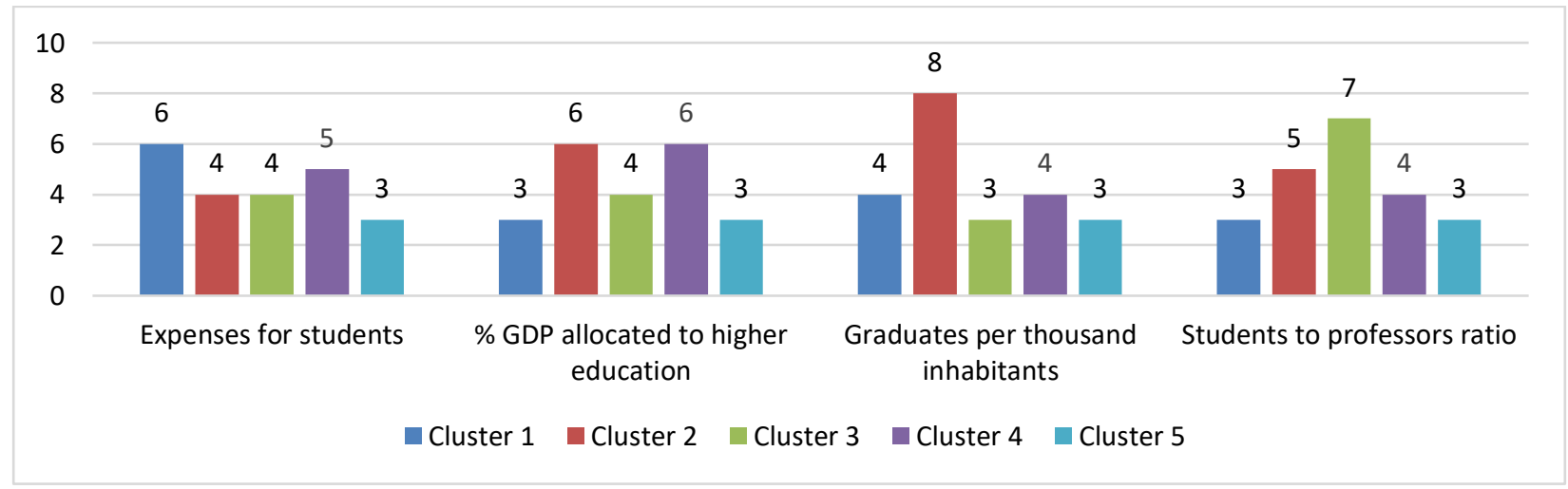

Figure 2. Number of countries in each cluster

Source: Eurostat and won computations, 2020. 
The following table shows the cluster associated with each country according to the analyzed indicators.

Table 1. Cluster distribution by selected indicators and EU countries

\begin{tabular}{|c|c|c|c|c|}
\hline & $\begin{array}{l}\text { Expenditure } \\
\text { per student }\end{array}$ & $\begin{array}{c}\% \text { GDP } \\
\text { allocated } \\
\text { to higher }\end{array}$ & $\begin{array}{c}\text { Graduates } \\
\text { per thousand } \\
\text { inhabitants }\end{array}$ & $\begin{array}{c}\text { Professor } \\
\text { per student's ratio }\end{array}$ \\
\hline Belgium & 1 & 2 & 2 & 5 \\
\hline Bulgaria & 5 & 5 & 3 & 3 \\
\hline Czech Republic & 3 & 5 & 2 & 3 \\
\hline Germany & 1 & 2 & 4 & 2 \\
\hline Estonia & 3 & 2 & 4 & 3 \\
\hline Ireland & 2 & 4 & 1 & 2 \\
\hline Greece & 5 & 4 & 4 & 5 \\
\hline Spain & 3 & 3 & 1 & 3 \\
\hline France & 2 & 2 & 1 & 2 \\
\hline Italy & 2 & 4 & 3 & 4 \\
\hline Cyprus & 3 & 3 & 2 & 4 \\
\hline Latvia & 4 & 4 & 4 & 4 \\
\hline Lithuania & 4 & 4 & 2 & 3 \\
\hline Hungary & 4 & 4 & 5 & 1 \\
\hline Malta & 2 & 2 & 3 & 1 \\
\hline Netherlands & 1 & 1 & 2 & 2 \\
\hline Austria & 1 & 1 & 2 & 2 \\
\hline Poland & 4 & 3 & 1 & 5 \\
\hline Romania & 5 & 5 & 5 & 4 \\
\hline Slovenia & 3 & 3 & 2 & 3 \\
\hline Sweden & 1 & 1 & 5 & 1 \\
\hline UK & 1 & 2 & 2 & 3 \\
\hline
\end{tabular}

From the table above it can be seen that Romania, along with Greece and Bulgaria, belongs to the last cluster in terms of government spending per student. Also, in terms of the percentage of GDP allocated to higher education, Romania is in the last cluster along with the Czech Republic and Bulgaria. Our country is also in the last cluster in terms of the number of higher education graduates from EU member states, along with Hungary and Sweden. In addition, in terms of the number of students per teacher, Romania is in the penultimate cluster, being ahead of Greece, Cyprus, Belgium and Italy in this ranking.

Figures A1-A4 from the Appendix show the distribution of EU Member States according to the cluster they belong to in each of the four indicators analyzed.

Another important result can be obtained when dividing into clusters by combining two indicators. Figure 3 shows the distribution of EU Member States according to the percentage of GDP allocated to higher education and the number of graduates per thousand inhabitants. 


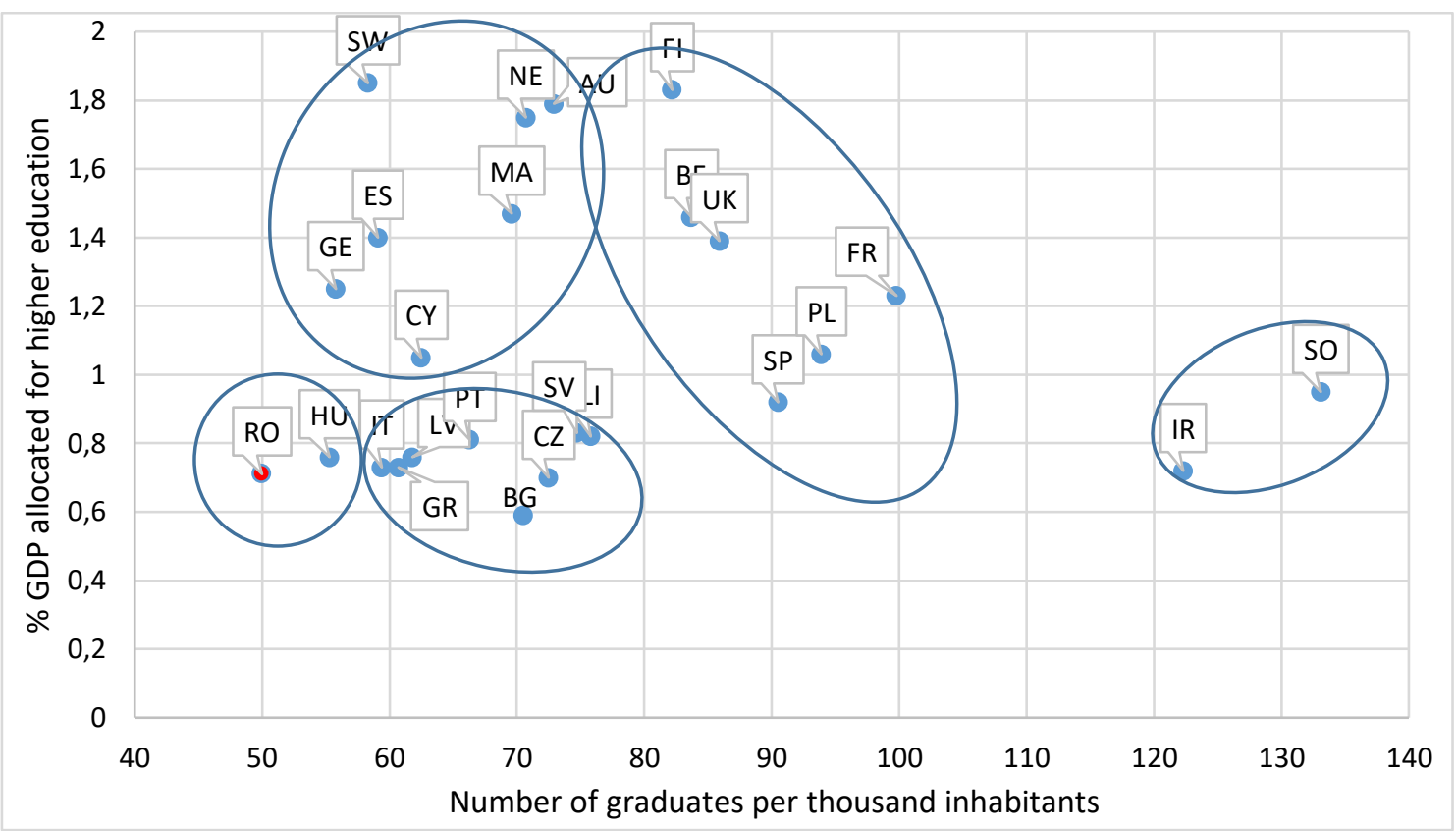

PICBE |

Figure 3. Distribution of countries in each cluster. The red dot represents the value associated with Romania

Source: Eurostat and won computations, 2020.

From the figure above it can be seen that Romania is in the same cluster along with Hungary. Figure 4 shows the distribution of EU Member States according to the percentage of GDP allocated to higher education and the number of students per teacher.

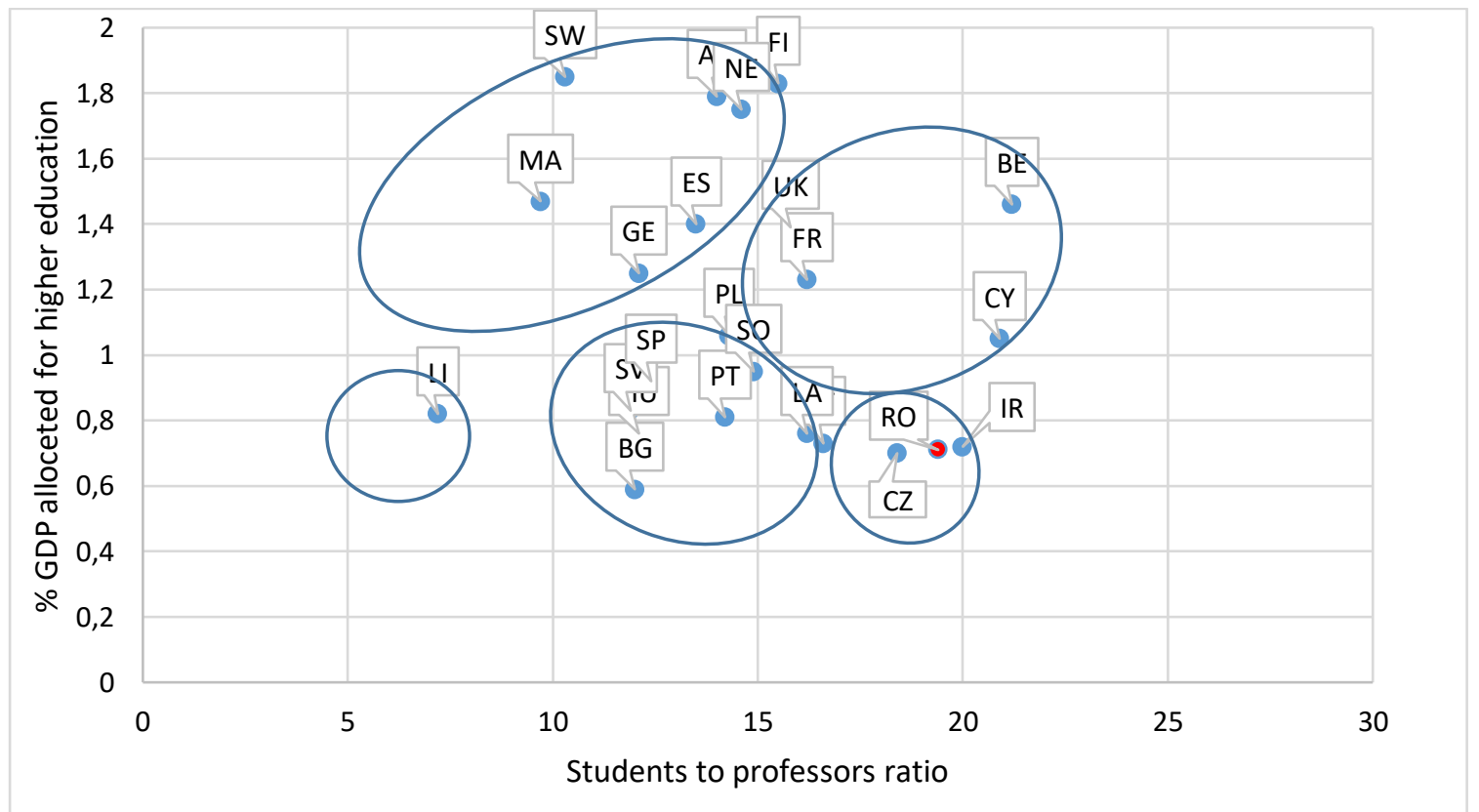

Figure 4. Distribution of countries in each cluster. The red dot represents the value associated with Romania

Source: Eurostat and won computations, 2020.

DOI: 10.2478/picbe-2021-0020, pp. 210-217, ISSN 2558-9652 |

Proceedings of the $15^{\text {th }}$ International Conference on Business Excellence 2021 
From the figure above it can be seen that Romania is in the same cluster along with the Czech Republic and Ireland.

\section{Conclusions and recommendations}

The modernization of the education system in Romania and its harmonization with the main characteristics of education in the EU countries is a long process, which takes place socially, culturally and economically.

Despite the development of several forms of education (part-time education, full-time education, distance learning), Romania and other EU member states need to be aware of the costs of managing them and supporting effective access, especially for disadvantaged groups in this area. of sight. At the same time, there is an obvious need to increase the employability of university graduates.

The cluster analysis developed in this paper, indicates that there are several indicators, related to higher education, where Romania has to improve, such as: expenditure per student, percentage of GDP allocated to higher education, number of graduates per thousand of inhabitants, while the only indicator at which Romania is competitive is the professor per student's ratio.

Capitalizing on the results of Romania's integration into the European Union requires additional efforts in this direction, the research showing the need for related measures to address both the specific levers of education and those aimed at harmonizing it with labor market requirements, employers' interest in supporting education and youth training.

The limitations of the research carried out at European level are related to the insufficiency of the statistical data needed for a detailed analysis, covering a longer period of time for all the indicators considered. The analysis was performed only for some of the indicators that can highlight the five four dimensions, for the same reason, namely the insufficiency of relevant statistical data.

Given that education has a strategic importance, both as a field of development of national plans and research, we consider it possible to conduct research in the future to analyze the correlations between its evolution and several indicators relevant to living standards, for increasing the performance in innovation and research and for the impact of education and development on the national economy.

\section{References}

Brennan, J., Locke, W., and Naidoo, R. (2007). United Kingdom: An increasingly differentiated profession. In: W. Locke and U. Teichler, eds. 2007. The Changing Conditions for Academic Work and Career in Selected Countries. Werkstattberichte series. Kassel, Germany: International Centre for Higher Education Research.

Curaj, A, Deca, L., and Hâj, C. M. (2015). Romanian Higher Education in 2009-2013. The Bologna process and Romanian priorities in the search for an active European and Global presence. Higher Education reforms in Romania, Dordrecht: Springer Publishing.

Eurostat (2015). Europe 2020 indicators - education. [online] Available at: http://ec.europa.eu/ eurostat/statistics-explained/index.php/Europe_2020_indicators_-_education, Accessed 10 February 2021.

Dima, A. M., \& Vasilache, S. (2016). Trends in the internationalization of European higher education in a convergence perspective, Management \& Marketing, 11(2). 
Dima, A. M., \& Meghisan-Toma, G. M. (2018). Research on implementing education for sustainable development. In Proceedings of the international conference on business excellence, 12(1), 300-310.

Dubickis, M., \& Gaile-Sarkane, E. (2015). Perspectives on innovation and technology transfer. Procedia-Social and Behavioral Sciences, 213, 965-970.

Goia, S., Marinaș, C. V., \& Igret, R. Ș. (2017). A plea for quality in internship programmesevidence from the business and administration students' experience, Management \& Marketing. Challenges for the Knowledge Society, 12(1), 49-60.

Koucky, J., Bartusek, A., and Kovarovic, J. (2010). Who gets a degree?: access to tertiary education in Europe 1950-2009, Prague, Charles University in Prague.

Paunescu, C., Drăgan, D., \& Găucă, O. (2017). Examining obligations to society for QS Stars best ranked universities in social responsibility, Management \& Marketing, Challenges for the knowledge society, 12(4), 551-570.

Reinalda, B. (2008). The ongoing Bologna process and political science, European Political Science, iss. 7, 389-393.

Shattock, M. (2014). The context of modernising reforms in university governance. International studies in higher education, New York, Deer Park Productions.

Thomas, L. (2002). Student retention in higher education: the role of institutional habitus, Journal of Education Policy, 17(4), 423-442.

\section{Appendix}

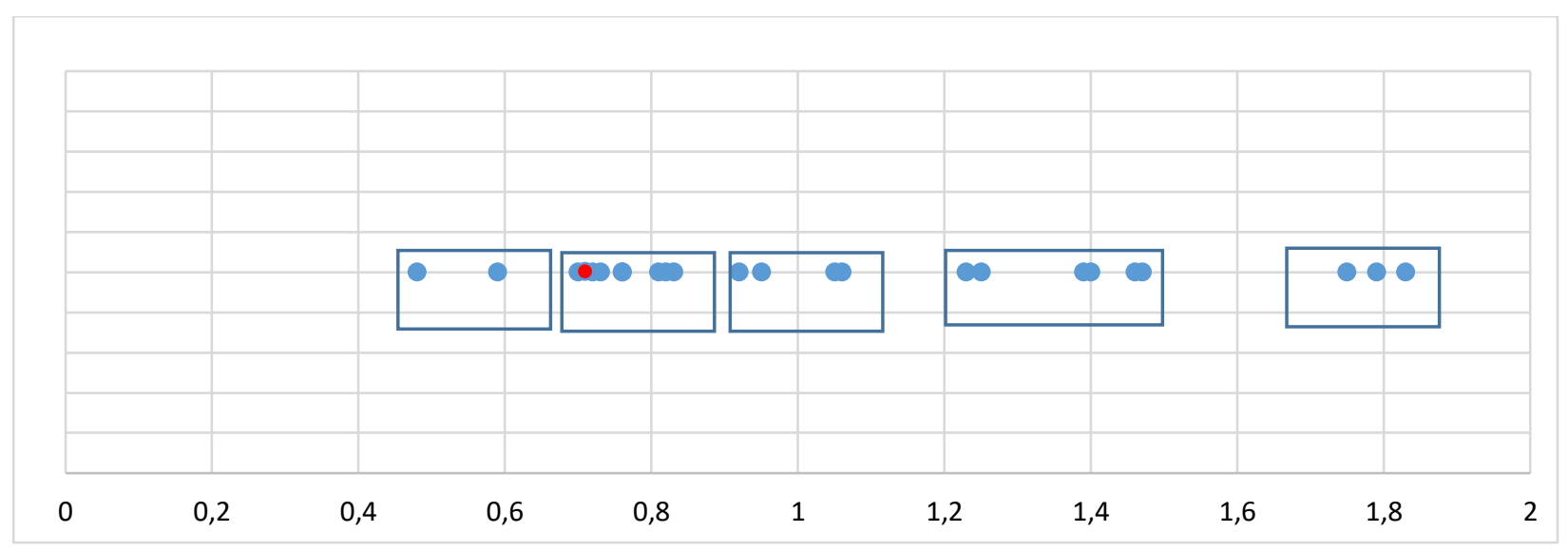

Figure A1. \% of GDP allocated to higher education

Source: Eurostat and won computations, 2020.

DOI: 10.2478/picbe-2021-0020, pp. 210-217, ISSN 2558-9652 |

Proceedings of the $15^{\text {th }}$ International Conference on Business Excellence 2021 


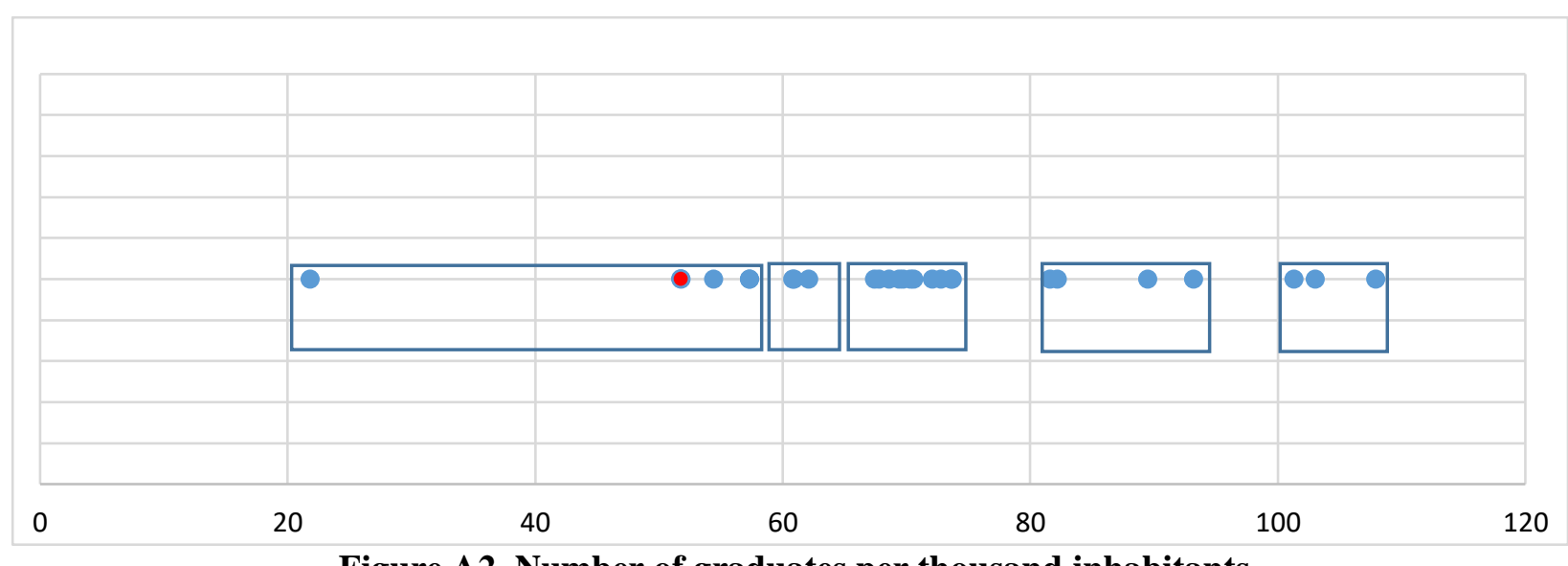

Figure A2. Number of graduates per thousand inhabitants

PICBE |

Source: Eurostat and won computations, 2020.

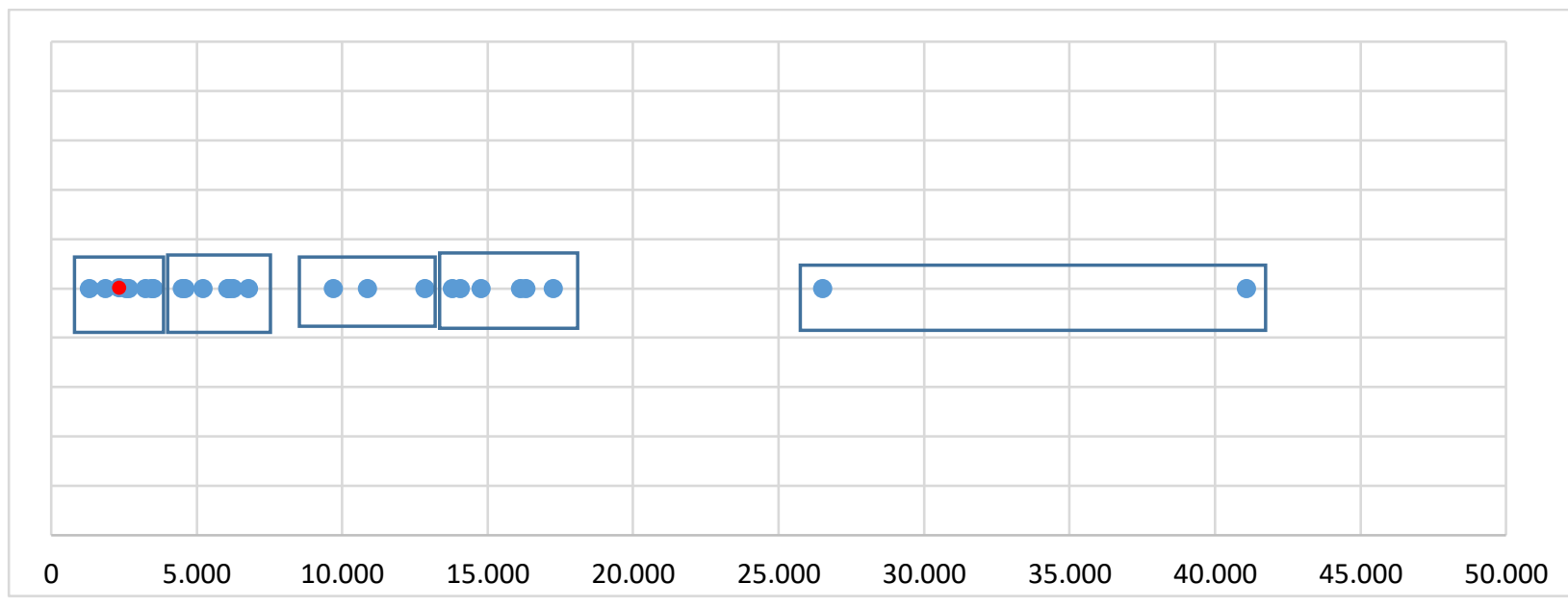

Figure A3. Expenditures for higher education

Source: Eurostat and won computations, 2020.

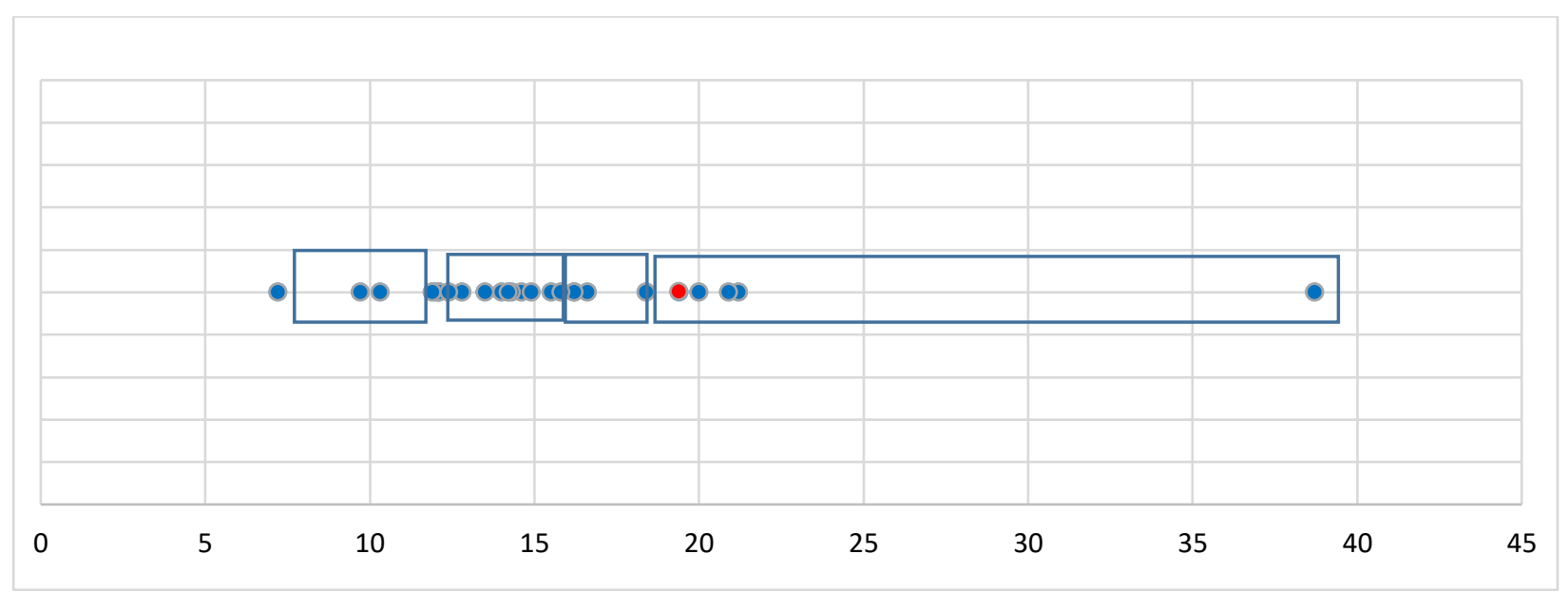

Figure A4. Number of students per professor ratio

Source: Eurostat and won computations, 2020.

DOI: 10.2478/picbe-2021-0020, pp. 210-217, ISSN 2558-9652 |

Proceedings of the $15^{\text {th }}$ International Conference on Business Excellence 2021 